\title{
Appendicular schistosomiasis: a cause of clinical acute appendicitis?
}

\author{
MB SATTI, DM TAMIMI, MO Al SOHAIBANI, A AL QUORAIN \\ From the Department of Pathology, King Faisal University, Dammam, Saudi Arabia
}

SUMMARY The role of schistosomes in the pathogenesis of acute appendicitis in an endemic area was investigated. Of 1600 appendicectomies received in our laboratory, 26 showed appendiceat? schistosomiasis, which prompted what we believe to be the first detailed histopathological evalu- $\overrightarrow{0}$ ation of all appendices with schistosomal infestation, without prior knowledge of the clinical and operative diagnoses. The results suggest that there are two types of schistosomal appendicitis, each $\vec{\perp}$ with distinct clinicopathological features and different pathogenetic mechanisms. They could be응 called obstructive and granulomatous schistosomal acute appendicitis, respectively.

Schistosomiasis of the appendix is a recognised phenomenon, the appendix being regarded as one of the ectopic sites for haematobium species. In a necropsy study of 96 patients Lima ${ }^{1}$ found appendiceal disease in four with "ectopic lesions" due to Schistosoma mansoni infestation. As far as we know there has been no previous detailed study on the role of schistosomiasis in the pathogenesis of acute appendicitis, even from endemic areas. In another necropsy study Smith $^{2}$ reported that Schistosoma haematobium eggs prefer the appendix, but the problem was not addressed by Abdel Wahab in his work on schistosomiasis in Egypt. ${ }^{3}$ In this paper we examine the role of schistosomes in the pathogenesis of acute appendicitis.

\section{Material and methods}

The material for this study was retrieved from the files of the pathology department of King Fahd Hospital, Al-Khobar, during 1982-1985. Of all the cases of acute appendicitis coming to surgery in that period, those showing schistosomal ova in the appendiceal wall were included in this study. Without prior knowledge of their clinical data or diagnoses, a detailed histopathological evaluation was performed on stained paraffin sections. Where necessary, sections were recut from retrieved paraffin blocks and stained with haematoxylin and eosin to investigate any correlation between presence of the ova and clinical presentation.

Histopathological critera recorded included the presence or absence of the following: active granu-

Accepted for publication 27 October 1986 lomatous inflammation with eosinophilic necrosis around ova; tissue eosinophilia; purulent exudate in $\vec{\omega}$ lumen, or wall, or both; fibrosis without a purulent $\stackrel{\infty}{\sim}$ exudate or active granulomas; and faecoliths. We considered that the appendix showed pathologicalo evidence of recent symptomatic inflammation if there were active granulomas with tissue necrosis (fig 1) or a purulent exudate in lumen or wall, or both. The first $\frac{\circ}{D}$ group were called schistosomal granulomatous acute $\varrho$ appendicitis and the second, schistosomal obstructive $\overrightarrow{0}$ acute appendicitis. Appendices that showed neither 3 active granulomas nor a purulent exudate, but only schistosomal ova occasionally accompanied by fibrosis and calcification (fig 2), were considered to용 show no pathological evidence of recent symptomatic $\dot{0}$ inflammation.

The patients' charts were reviewed for information $ᄋ$ on age, sex, symptoms and duration, signs, clinical diagnosis, operative findings and the white cello counts, including the neutrophil and eosinophil counts.

\section{Results}

Of 16000 surgical specimens, 1600 were appen- స్ట dicectomies. On histopathological review, $1400(87 \%)$ showed transmural acute appendicitis. In all, 26 caseso of appendiceal schistosomiasis were found. Of these, $\overline{\mathbb{D}}$ 19 showed pathological evidence of recent symptom $-?$ atic inflammation. Eleven of these qualified for inclu- -7 sion in the group with schistosomal obstrucive acute $\frac{\vec{T}}{\mathbb{D}}$ appendicitis and eight for inclusion in the group with schistosomal granulomatous acute appendicitis. The $\stackrel{\mathbb{Q}}{\varrho}$ remaining seven did not show pathological evidence of recent symptomatic inflammation. Severe fibrosis 


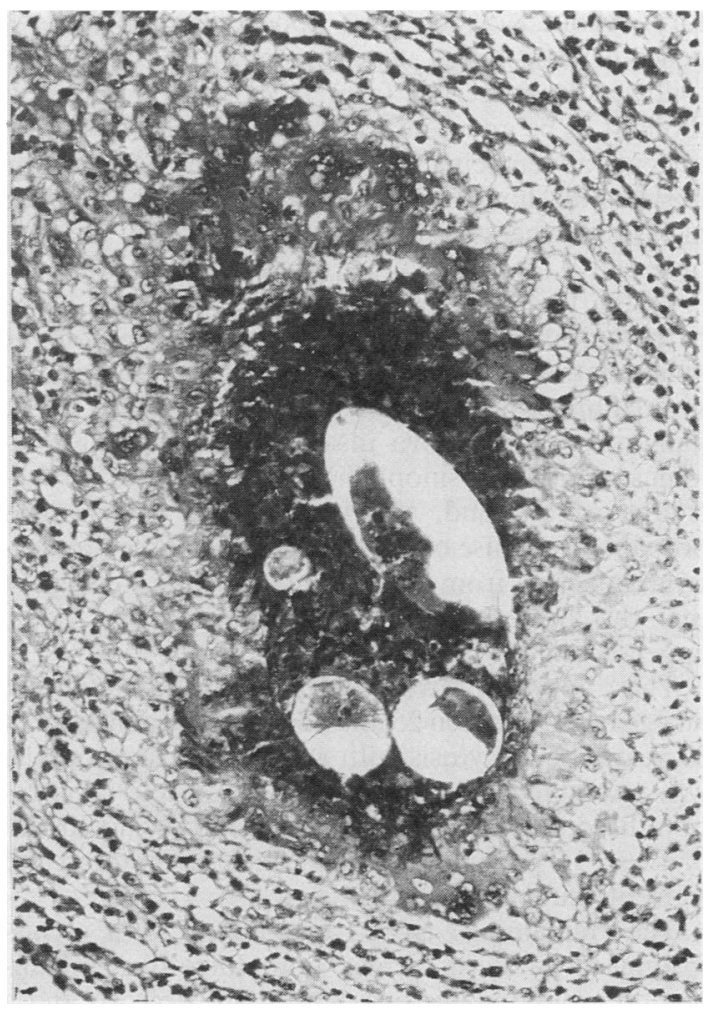

Fig 1 Appendix with active granulomatous reaction and tissue necrosis. (Haematoxylin and eosin.) $\times 375$.

of the wall with numerous calcified ova was the pathological hall mark of this group. Interestingly, fibrosis and calcification of ova were consistently present in the wall of appendices that showed purulent exudation (fig 3), which was not a conspicuous feature of appendices with active granulomas and eosinophils in the wall.

Table 1 summarises the clinicopathological correlation between these patients. Of the 21 patients with clinically diagnosed acute appendicitis, 19 had histopathological evidence of recent symptomatic inflammation, accounting for the symptoms and signs. The remaining two showed no pathological evidence of recent symptomatic inflammation. The three patients with clinically diagnosed chronic appendicitis showed no pathological evidence of recent symptomatic inflammation. In one of these three patients the appendix had been removed during cholecystectomy because of chronic cholecystitis. Two patients had clinically diagnosed ureteric obstruction, and their appendices were removed. No pathological evidence of recent symptomatic inflammation was found in either case.

Table 2 shows the information on age, sex, and

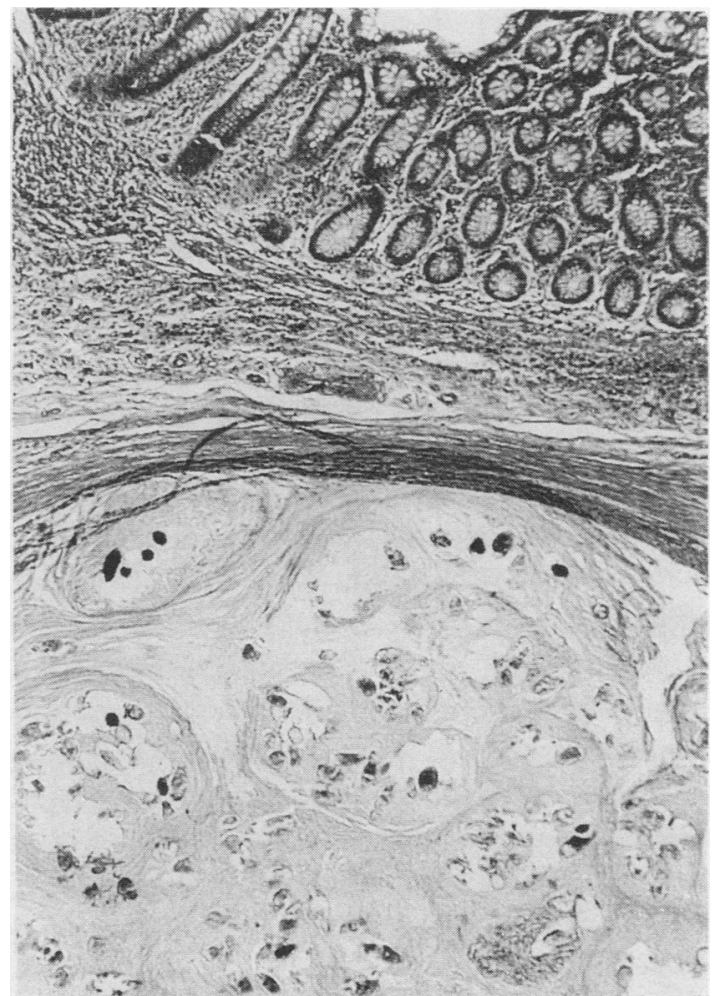

Fig 2 Appendix with schistosomal ova and fibrosis in wall. Note absence of granulomas and purulent exudation. (Haematoxylin and eosin.) $\times 125$.

white cell counts of patients with schistosomal obstructive appendicitis. Table 3 shows that pertaining to patients with schistosomal granulomatous acute appendicitis, and table 4 that of patients with appendices without pathological evidence of recent symptomatic inflammation.

\section{Discussion}

Acute appendicitis is a common clinical problem. Surgically removed appendices comprise $10 \%$ of material coming to our surgical pathology labora-

Table 1 Summary of clinicopathological correlation of patients with appendiceal schistosomiasis

\begin{tabular}{llll}
\hline & & \multicolumn{2}{l}{ Pathological diagnosis } \\
\cline { 3 - 4 } Clinical diagnosis & $\begin{array}{l}\text { No of } \\
\text { patients }\end{array}$ & $\begin{array}{l}\text { Recent symptomatic } \\
\text { inflammation }\end{array}$ & Not inflamed \\
\hline $\begin{array}{l}\text { Acute appendicitis } \\
\text { Chronic } \\
\text { appendicitis }\end{array}$ & 21 & 19 & 2 \\
$\begin{array}{l}\text { Incidental removal } \\
\text { at ureteric } \\
\text { exploration }\end{array}$ & 2 & 3 & 2 \\
\hline
\end{tabular}




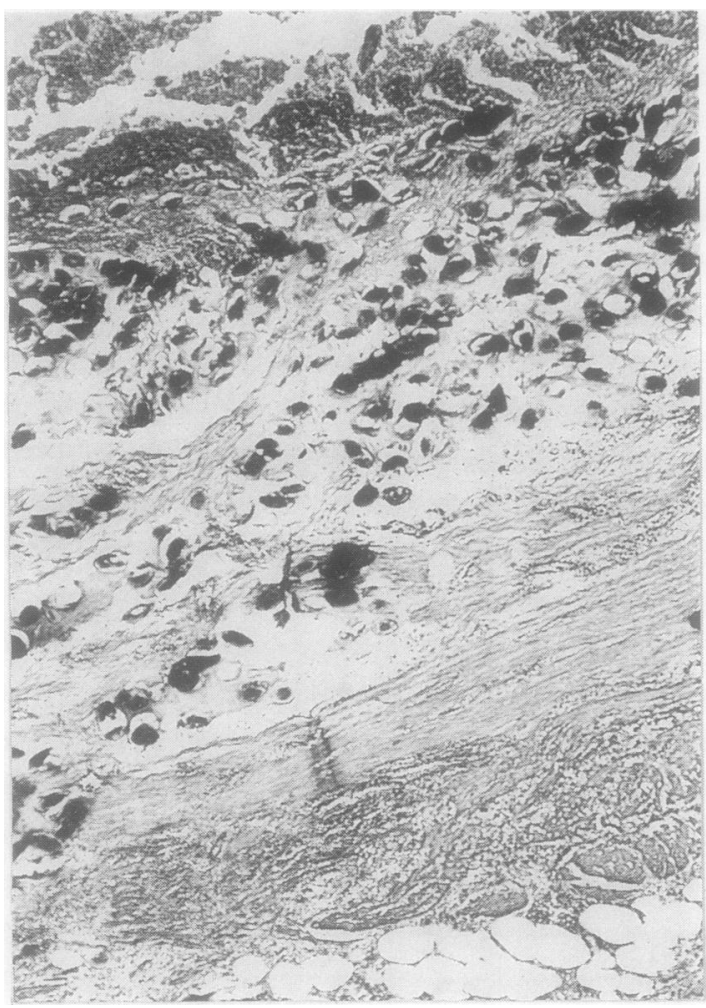

Fig 3 Appendix with fibrosis and calcification in wall in presence of purulent exudation. (Haematoxylin and eosin.) $\times 320$.

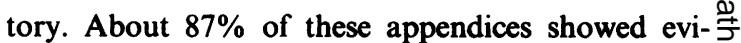

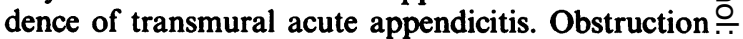
followed by infection from faecal contaminants is $\overrightarrow{\vec{F}}$ thought to be an important pathogenetic mechanism in acute appendicitis. ${ }^{4}$ Objective evidence of such an? obstruction, however, is found only in a proportion $\frac{\bar{\sigma}}{\bar{c}}$ of cases, further emphasising the existence of the non- $\vec{\otimes}$ obstructive form of acute appendicitis.

Of the 19 appendices with schistosomal and histo- $ळ$ pathological evidence of recent symptomatic $\vec{\circ}$ inflammation, 11 showed suppuration in addition to severe fibrosis of a portion of the wall, induced by the $\vec{\omega}$ numerous calcified ova inside it. No active granulomas or tissue eosinophilia were noted. As no fae-? coliths were found, the schistosomal fibrosis was $\overrightarrow{0}$ probably the cause of the obstruction that led to bac- $\rightarrow$ terial infection from faecal contaminants: we suggest $\stackrel{i}{\mathrm{~N}}$ that this be termed schistosomal obstructive acute appendicitis.

These appendices were all from male patients, with $\vec{\longrightarrow}$ an age range between 25 and 45 years and a median of 39 years. Leucocytosis with an absolute neutrophilia was a notable feature, in keeping with bacterial infec- $\vec{\varphi}$ tion. Blood eosinophilia was occassionally noted. All. of these 11 patients had the typical symptoms and signs of acute appendicitis.

The remaining eight appendices with schistosomiasis showed active granulomatous inflammation around viable ova, with tissue necrosis and $a \frac{2}{\otimes}$ tissue eosinophilia. No obstruction was noted, and $\stackrel{\varrho}{\Rightarrow}$ neutrophil exudation was not a feature. All of these $\frac{0}{3}$ patients presented with typical symptoms and signs of

Table 2 Schistosomal obstructive acute appendicitis

\begin{tabular}{|c|c|c|c|c|c|c|}
\hline Case No & Age & $\operatorname{Sex}$ & $\begin{array}{l}\text { White cell count } \\
\times 10^{9} / 1\end{array}$ & Neurophil \% & $\begin{array}{l}\text { Absolute } \\
\text { neutrophils } \times 10^{9} / l\end{array}$ & Eosinophil \% \\
\hline $\begin{array}{r}1 \\
2 \\
3 \\
4 \\
5 \\
6 \\
7 \\
8 \\
9 \\
10 \\
11\end{array}$ & $\begin{array}{l}43 \\
38 \\
42 \\
39 \\
45 \\
29 \\
40 \\
34 \\
36 \\
25 \\
40\end{array}$ & $\begin{array}{l}\mathbf{M} \\
\mathbf{M} \\
\mathbf{M} \\
\mathbf{M} \\
\mathbf{M} \\
\mathbf{M} \\
\mathbf{M} \\
\mathbf{M} \\
\mathbf{M} \\
\mathbf{M} \\
\mathbf{M}\end{array}$ & $\begin{array}{r}12.5 \\
8.9 \\
11.8 \\
13 \\
9.3 \\
11.3 \\
13.4 \\
12.8 \\
11.3 \\
6.4 \\
8.7\end{array}$ & $\begin{array}{l}91 \\
57 \\
70 \\
75 \\
64 \\
65 \\
50 \\
77 \\
88 \\
60 \\
73\end{array}$ & $\begin{array}{r}11.4 \\
5.1 \\
8.3 \\
9.8 \\
6.0 \\
7.4 \\
6.7 \\
9.9 \\
9.9 \\
3.8 \\
6.4\end{array}$ & $\begin{array}{r}0 \\
10 \\
4 \\
3 \\
2 \\
3 \\
5 \\
6 \\
0 \\
17 \\
1\end{array}$ \\
\hline
\end{tabular}

Table 3 Schistosomal granulomatous acute appendicitis

\begin{tabular}{|c|c|c|c|c|c|c|}
\hline Case No & Age & Sex & $\begin{array}{l}\text { White cell count } \\
\times 10^{9} / l\end{array}$ & Neutrophil \% & $\begin{array}{l}\text { Absolute } \\
\text { neutrophils } \times 10^{9} / l\end{array}$ & Eosinophil \% \\
\hline $\begin{array}{l}1 \\
2 \\
3 \\
4 \\
5 \\
6 \\
7 \\
8\end{array}$ & $\begin{array}{l}27 \\
30 \\
23 \\
25 \\
17 \\
30 \\
18 \\
19\end{array}$ & $\begin{array}{l}\mathbf{M} \\
\mathbf{M} \\
\mathbf{M} \\
\mathbf{M} \\
\mathbf{M} \\
\mathbf{M} \\
\mathbf{M} \\
\mathbf{M}\end{array}$ & $\begin{array}{r}6.8 \\
9 \cdot 3 \\
4.7 \\
7.0 \\
12.2 \\
8.6 \\
6.5 \\
7 \cdot 1\end{array}$ & $\begin{array}{l}52 \\
70 \\
29 \\
45 \\
65 \\
59 \\
55 \\
68\end{array}$ & $\begin{array}{l}3.5 \\
6.5 \\
1.4 \\
3 \cdot 2 \\
7.9 \\
5 \cdot 1 \\
3.6 \\
4.8\end{array}$ & $\begin{array}{r}7 \\
3 \\
2 \\
2 \\
1 \\
3 \\
10 \\
13\end{array}$ \\
\hline
\end{tabular}


Table 4 Appendices without pathological evidence of recent symptomatic acute inflammation

\begin{tabular}{|c|c|c|c|c|c|c|}
\hline Case No & Age & Sex & Clinical diagnosis & $\begin{array}{l}\text { White cell count } \\
\times 10^{9} / l\end{array}$ & Neutrophil \% & $\begin{array}{l}\text { Absolute } \\
\text { neutrophils } \times 10^{9} / l\end{array}$ \\
\hline $\begin{array}{l}1 \\
2 \\
3 \\
4 \\
5 \\
6 \\
7\end{array}$ & $\begin{array}{l}35 \\
18 \\
40 \\
30 \\
45 \\
26 \\
25\end{array}$ & $\begin{array}{l}\mathbf{M} \\
\mathbf{M} \\
\mathbf{M} \\
\mathbf{M} \\
\mathbf{M} \\
\mathbf{M} \\
\mathbf{M}\end{array}$ & $\begin{array}{l}\text { Acute appendicitis } \\
\text { Acute appendicitis } \\
\text { Chronic appendicitis } \\
\text { Chronic appendicitis } \\
\text { Cholecystectomy } \\
\text { Ureteric obstruction } \\
\text { Ureteric obstruction }\end{array}$ & $\begin{array}{l}6 \cdot 8 \\
5 \cdot 6 \\
6 \cdot 6 \\
3 \cdot 3 \\
5 \cdot 3 \\
6 \cdot 3 \\
7 \cdot 2\end{array}$ & $\begin{array}{l}65 \\
54 \\
50 \\
48 \\
63 \\
64 \\
64\end{array}$ & $\begin{array}{l}4 \cdot 4 \\
3 \cdot 0 \\
3 \cdot 3 \\
1 \cdot 6 \\
3 \cdot 3 \\
4 \cdot 0 \\
4 \cdot 6\end{array}$ \\
\hline
\end{tabular}

Table 5 Two disease states of schistosomal acute appendicitis

\begin{tabular}{lll}
\hline Feature & Granulomatus & Obstructive \\
\hline Sex & Male & Male \\
Age range (years) & $17-30$ & $25-45$ \\
Median & 23 & 39 \\
Total white cells & Normal or mild leucocytosis & Leucocytosis \\
Neutrophils (blood) & Normal & Increased \\
Granulomas with tissue necrosis & Present & Absent \\
Tissue eosinophils & Numerous & Relatively few \\
Purulent exudate & Absent & Present \\
Fibrosis and calcification of wall & Absent & Present \\
Faecolith & Absent & Absent \\
Pathogenesis & Immunological & Bacterial: follows fibrotic obstruction \\
Time of occurrence after infestation & Early (weeks) & Late (months to years) \\
\hline
\end{tabular}

acute appendicitis; we suggest that this be termed schistosomal granulomatous acute appendicitis. These patients were all men, but of a relatively younger age, 17 to 30 years and a median of 23 years. Their total white cell counts were either normal or low-high in contrast to patients in the group with obstructive appendicitis who, except one, had total white cell counts above $8.7 \times 10^{9} / 1$. Absolute neutrophilia was noted in most of the patients with schistosomal obstructive acute appendicitis. Blood eosinophilia was noted in some cases, and was not an important differentiating feature between the two disease states.

Granulomatous tissue destruction is probably the direct cause of symptoms and signs in patients with schistosomal granulomatous acute appendicitis. The granuloma formation is most likely a host immunological reaction to a product of the ova, the so called soluble egg antigen (SEA). ${ }^{5}$ It has been speculated that granuloma formation reaches its maximal size several weeks after onset of egg laying and thereafter decreases around eggs newly deposited in tissues. This phenomenon was originally called endogenous desensitisation. ${ }^{67}$ In support of this theory of an immunological reaction to recently deposited eggs, one of the appendices with active granulomatous inflammation that we studied showed a viable schistosomal worm in a venous channel of the appendiceal wall, probably indicating recent ova laying (fig 4). The relatively younger age of patients with schistosomal granulomatous acute appendicitis further supports this theory, indicating a probably recent infection with schistosomes.
Granulomatous inflammation of the appendix has been reported to be the direct cause of symptoms and signs of acute appendicitis. Fourteen of 19 patients with isolated Crohn's disease of the appendix had a history of less than 72 hours and a clinical dignosis of acute appendicitis. ${ }^{8}$ In another series ${ }^{9} 22$ of the reviewed 31 cases with primary Crohn's disease of the appendix had a preoperative diagnosis of acute appendicitis. In a third series ${ }^{10}$ six of 12 patients with Crohn's disease of the appendix had a disease history of one to three days. Vague right lower abdominal pain due to granulomatous appendicitis, presumably secondary to yersinial infection was reported in three cases. ${ }^{11}$ Tuberculosis ${ }^{12-14}$ and sarcoidosis ${ }^{15}$ were also reported to offset the appendix and produce symptoms and signs of acute appendicitis. In all of these cases and in schistosomal granulomatous acute appendicitis it was the granulomatous destruction of tissue that was the direct cause of pain in the absence of purulent exudation.

The data presented suggest that schistosomes could cause acute appendicitis via either one of two pathogenetic pathways. The recently deposited ova might induce an immunological granulomatous reaction leading to tissue destruction and thus directly leading to acute appendicitis (schistosomal granulomatous acute appendicitis). This occurs in younger patients during the early phase of egg laying in the appendix. Neutrophil leucocytosis is not a characteristic feature. Schistosomes could also result in acute appendicitis via an indirect pathway. Excessive fibrosis, the result of long standing inflammation and calcified ova in the 
wall, could lead to obstruction followed by bacterial infection, which occurs in other forms of obstructive acute appendicitis.

The presence of schistosomal ova in the wall of the appendix is not always symptomatic. Appendices with schistosomal ova but without pathological evidence of recent symptomatic inflammation were removed in seven instances (table 4). In three patients this occurred during either exploration for ureteric obstruction (two patients) or cholescystectomy (one patient). There were no symptoms or signs referrable to the appendix. In two instances the indication for removal was vague symptoms referred to as chronic appendicitis. Two other patients had a clinical diagnosis of probable acute appendicitis, which was not confirmed at operation or histologically. In all seven patients the total white cell counts were normal, with a normal neutrophil count but an occasional eosinophilia. They were all men with an age range of 18 to 45 years and a median of 30 years. These fibrotic appendices containing the calcified schistosomal ova were asymptomatic. If left alone, they are probably the precursor lesion of schistosomal obstructive acute appendicitis, which occurred in an older age group (median 39 years).

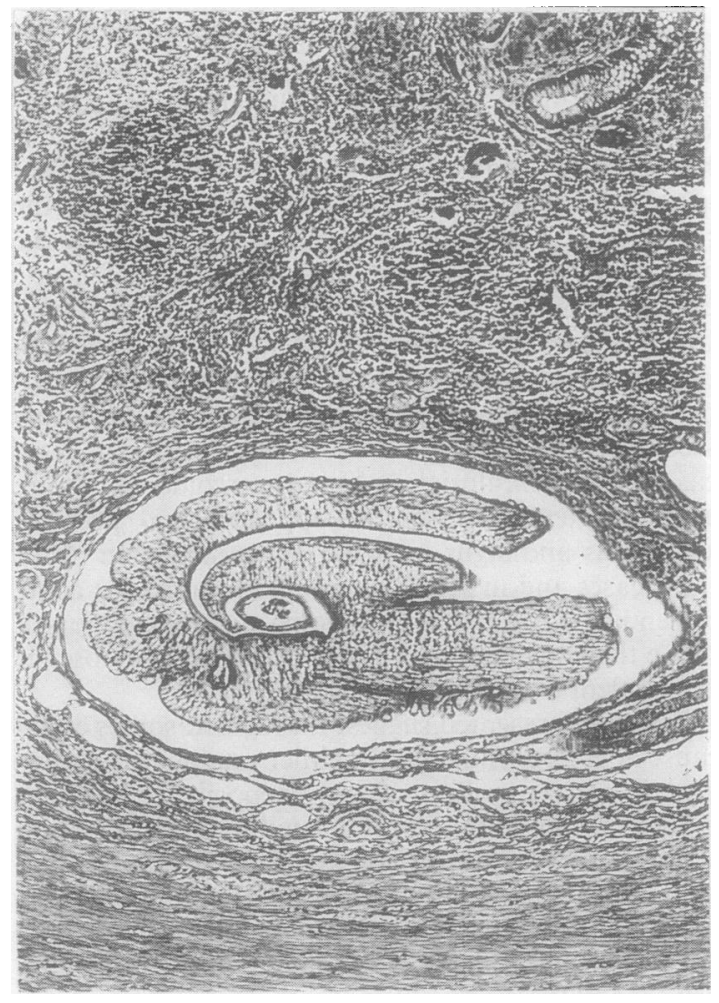

Fig 4 Appendix with viable schistosomal worm in venous channel in wall. (Haematoxylin and eosin.) $\times 125$.
In conclusion, we believe that schistosomal acute $\stackrel{0}{*}$ appendicitis is a definite clinicopathological entity. It occurs in about $1.5 \%$ of all cases of an appendicitis like syndrome presenting to surgeons practising in endemic areas. The mere presence of schistosomal 0 ova in the appendix without a purulent or granu- $\frac{}{\sigma}$ lomatous inflammatory reaction is, on the whole, $\frac{\bar{\rho}}{\bar{\sigma}}$ asymptomatic, but the resulting fibrosis may later $\stackrel{\oplus}{\circ}$ produce the obstructive form of schistosomal acute appendicitis. Schistosomal acute appendicitis exists as two disease states that differ in some of their clinical and histopathological features, as well as in their pathogenic mechanisms (table 5).

We thank Mr Andrew Archibald for his help with the half tones, and Mrs Lolita Galdones-Santos for her secretarial help.

\section{References}

1 Lima JPR. Study of the so called ectopic lesions in schistosoma mansoni infections. I: General incidence. Revista Do Instituto De Medicina Tropical de Sao Paulo 1962; 8(4):167-72.

2 Smith JH, Kamel IA, Elwi A, Von Lichtenberg F. A quantitative post-mortem analysis of urinary schistosomiasis in Egypt. I. Pathology and pathogenesis. Am $J$ Trop Med Hyg 1974:23:1054-71.

3 Abdel Wahab MP. Schistosomiasis in Egypt. Florida: CRC, 1982.

4 Rosai J. Ackerman's surgical pathology volume I. 6th Ed. St Louis: CV Mosby Company, 1981

5 Pelley RP, Pelley RJ. In: Van den Bossche, ed. Schistosoma mansoni soluble egg antigen. Biochemistry of parasites and host parasite relationships. Amsterdam: Biomedical Press, 1976:283.

6 Domingo EO, Warren KS. Endogenous desensitization: changing host granulomatous response to schistosome eggs at different stages of infection with Schistosoma mansoni. Am J Patho 1968;52:369-79.

7 Colley DG, Heiny SE, Bartholomew RK, Cook JA. Immune responses during human schistosomiasis mansoni. Regulatory effects of patients' sera on human lymphocytes blastogenic ? responses to schistosome antigen preparation. Am J Trop Med $\overline{0}$ Hyg 1977;26:917-25.

8 Allen DC, Biggart JD. Granulomatous disease of the vermiform appendix. J Clin Pathol 1983;36:632-8.

9 Yang SS, Gibson P, McCaughey RS, Arcari FA, Bertnstein J. Primary Crohn's disease of the appendix. Report of 14 cases 을 and review of the literature. Ann Surg 1979;189:334-9.

10 Lindhagen T, Ekelund G, Leandoer L, Hildell J, Lindstrom C, $\frac{D}{O}$ Wenckert A. Crohn's disease confined to the appendix. Diseases of the colon and rectum 1982;25:805-8.

11 Payan HM, Gilbert EF, Hafez R. Granulomatous appendicitis. of Dis Colon Rectum 1981;24:432-6.

12 Koster H, Kasman LP. Tuberculosis of the appendix. Arch Surg N 1934;28:1149-65.

13 Kini MG. Primary tuberculosis appendicitis. Indian $J$ Surg 1942;4:34-47.

14 Morrison H, Mixter CG, Schlesinger MJ, Ober WB. Tuberculosis localized in the vermiform appendix. $N$ Engl $J$ Med 1952;246:329-31.

15 Clarke L, Pollett W, Chittal S, Ra Mu. Sarcoidosis with involvement of the appendix. Arch Intern Med 1983;143:1603-4

Requests for reprints to: Dr MB Satti, Department of Pa- $\stackrel{\mathbb{Q}}{\stackrel{Q}{2}}$ thology, College of Medicine and Medical Sciences, King $O$ Faisal University, PO Box 2114, Dammam 31451, Kingdom of Saudi Arabia. 